\title{
Publication Announcement
}

The Directory of Doctoral Programs in Theatre Studies, Performance Studies, AND DANCE: USA AND CANADA, 1996

A comprehensive guide to 45 doctoral programs.

\author{
Published by \\ American Society for Theatre Research
}

\section{EDITORS}

Peter A. Davis, University of Illinois

Thomas Postlewait, Ohio State University

\section{Features}

Detailed Description of Each Doctoral Program

Faculty Degree requirements for $\mathrm{PhD}$ and $\mathrm{MA}$

Tuition and Fees - Financial Aid

Scholarships - Library Resources - Recent Dissertations

Administrative Structure - Departmental Affiliations

Theatre Facilities and Production Schedules - Forthcoming Changes

Colleges and Universities Where Graduates Are Teaching

\section{TO ORDER}

Join ASTR! Membership includes the directory, the journal Theatre Survey, and the ASTR newsletter.

Full members $\$ 45$, students $\$ 25$, retirees $\$ 30$, members outside of North America $\$ 50$.

Send check to ASTR Records, Department of Theatre, Box 1897, Brown University, Providence, RI 02912

$$
\text { or }
$$

Order directory only: $\$ 15$ (\$19 Canada) + \$3.75 shipping per book; 1-800-881-9421 


\section{CALL FOR PAPERS PERformanCE: MODERN AND POSTMODERN}

For a special issue (or issues), Theatre Survey invites essays considering how twentieth-century performances, modern and postmodern, have put the "classics" into play, essays that theorize and clarify modern and/or postmodern theatrical practices. We take "classic" to embrace the familiar landmarks of the Western canon, from the Greeks through Beckett, Brecht, and beyond-and of the Eastern canon, as well as intercultural intersections between. Essays should engage specific productions directly but in ways that move beyond performance reconstruction to theorize and clarify the underlying forces of cultural production; essays should bring performances into dialogue with broader cultural and historical concerns.

Among the many questions that might be addressed: What is the place of "text" in modernist or postmodernist performance practice? What claims did modernist production make? What is the cultural

(ideological, political) "work" of modernist or postmodernist

"classics" in production? Who controls such production of the "classics?" What are the characteristics of the language of modernist scene design? How does the postmodern scenic vocabulary differ? What are the politics, the aesthetics of the Western postmodern appropriation of Eastern theatre practices?

Essays must be received by January 1, 1997. Submit three copies, prepared according to the Chicago Manual of Style, 14th Edition, to either of the editors for this project:

Gary Jay Williams, Editor Theatre Survey

Department of Drama

The Catholic University of America Washington, D.C. 20064
William Worthen Department of Theatre Northwestern University 1979 South Campus Drive Evanston, IL 60208-0234 


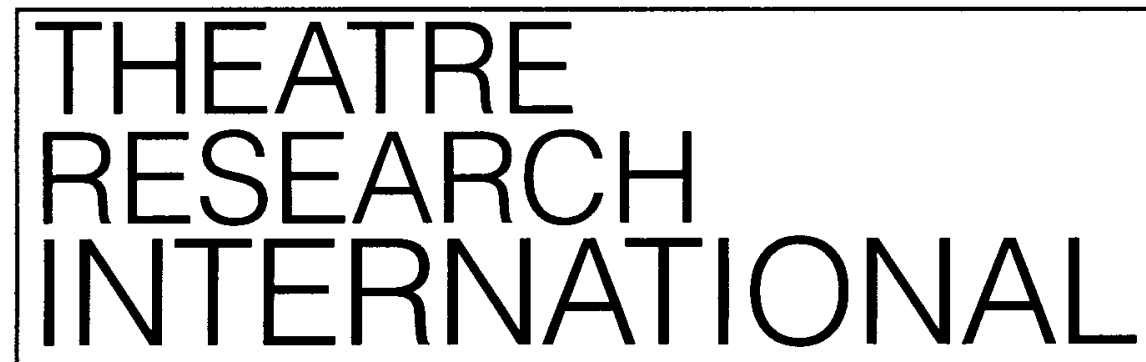

Edited by Claude Schumacher, Glasgow University

Theatre Research International publishes original articles on world theatre. Its focus is broad, highlighting such areas as theory and practice in the history of theatre, performance theory and analysis, theatre aesthetics, and new developments in theatre research.

The journal carries reviews of the most important studies in the field. It provides both a medium of communication for scholars, and a service to students of art, architedentie, design, music, and drama literature.

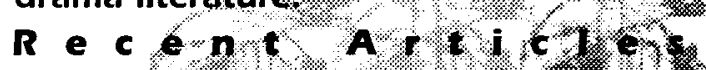

Tim Fitzpatrick Shakeseeares Exploitation of \& w Wo 1 Ooor

Stage: Macbeth

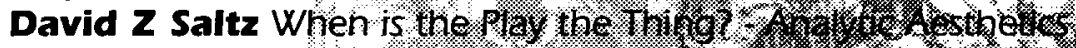
and Dramatic Theory:

Erika Fischer-Lichte from Theatre to Theatricallity tow to Construct Reality

Therese Malachy Jeakpaul Sartre playwright and the

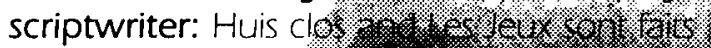

\section{Order Form \\ Volume 21 ( 3 issues) USS115/£60}

$\square$ Please send me a free sample copy.

$\square$ Please enter my 1996 subscription to Theatre Research International.

$\square$ I enclose a check payable to Oxford University Press.

$\square$ Please charge my Mastercard/Visa/American Express/Diners/JCB Card.

Card Number:

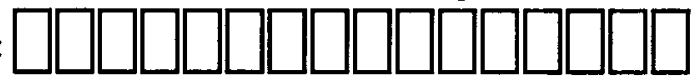

Exp. Date:

Signature.

- Please note: $\mathrm{f}$ Sterling rates apply in UK and

Europe, USS rates etsewhere. Custioners in the EU and $\mathrm{C}$

PLEASE PRINT DETAILS

Oxford University Press (X96) Journals Marketing 2001 Evans Road Cary NC 27513 USA

Tel: USA \& Canada Only 18008527323 or 9196770977 Fax: 9196771714 


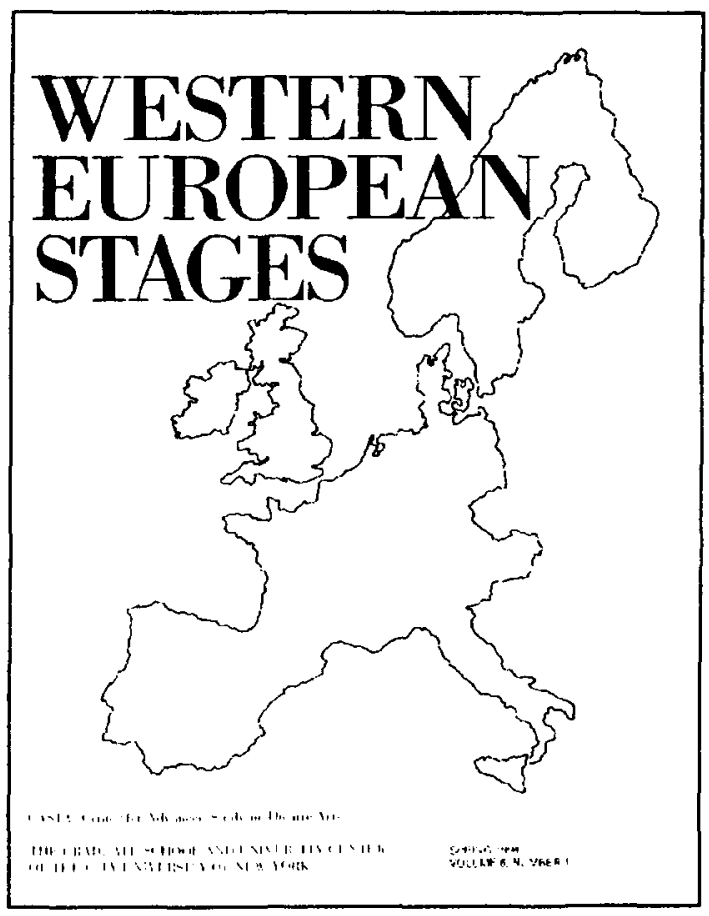

An indispensable resource in keeping abreast of the latest theatre developments in Western Europe. Issued three times a year - Spring, Winter and Fall - and edited by Marvin Carlson, each issue contains a wealth of information about recent European festivals and productions, including reviews, interviews, and reports. The 1996 Special Issue is devoted to contemporary women directors. Winter issues focus on the theatre in individual countries or on special themes. News of forthcoming events: the latest in changes in artistic directorships, new plays and playwrights, outstanding performances, and directorial interpretations. - \$15 per annum ( $\$ 19.00$ foreign).

Please send me the following CASTA publication:

Westem European Stages

@ $\$ 15.00$ per year

(Foreign) $\$ 19.00$ per year
Send order with enclosed check to: CASTA, CUNY Graduate Center 33 West 42nd Street

New York, NY 10036 


\title{
THE AMERICAN SOCIETY FOR THEATRE RESEARCH
}

The American Society for Theatre Research (ASTR) was founded in 1956 to encourage theatre scholarship and to provide a link with other similar groups represented in the International Federation for Theatre Research. The ASTR is the only American theatre organization affiliated with the American Council of Learned Societies and the International Federation for Theatre Research (IFTR/FIRT). In 1967 the ASTR was incorporated under the laws of New Jersey as a nonprofit corporation. In informal correspondence, the society is referred to as "ASTR."

Theatre Survey, the official joumal of ASTR, is published bianually in May and in November. The ASTR annual meeting occurs in the fall of each year.

Inquiries about ASTR, including membership, should be sent to

\author{
ASTR Records \\ Department of Theatre \\ Box 1897 \\ Brown University \\ Providence, RI 02912
}

ASTR membership includes a subscription to Theatre Survey. ASTR annual dues are $\$ 45$ for North American institutions and individuals, $\$ 50$ for non-North American institutions and individuals, $\$ 25$ for students, and $\$ 30$ for retirees.

\section{OFFICERS AND EXECUTIVE COMMITTEE OF ASTR}

Thomas Postlewait, President (1994-97)

Gresdna Doty, Vice-President (1994-97)

Don B. Wilmeth, Secretary (1995-98)

Albert Wertheim, Treasurer (1994-97)

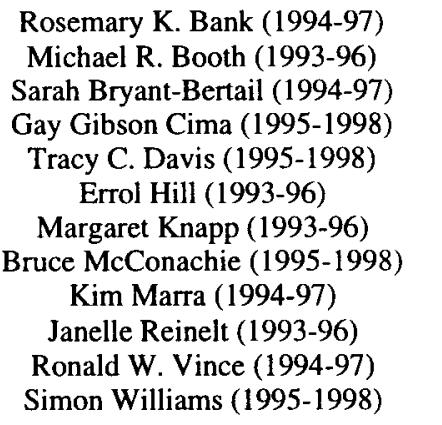

\section{EX-OFFICIO}

Sarah Blackstone, Richard M. Buck, Kalman A. Burnim, Phyllis T. Dircks, Joseph Donohue, Michal Kobialka, Felicia Londré, Bruce McConachie, Cary Mazer, Tice L. Miller, Stephen M. Vallillo, Simon Williams, Don B. Wilmeth 

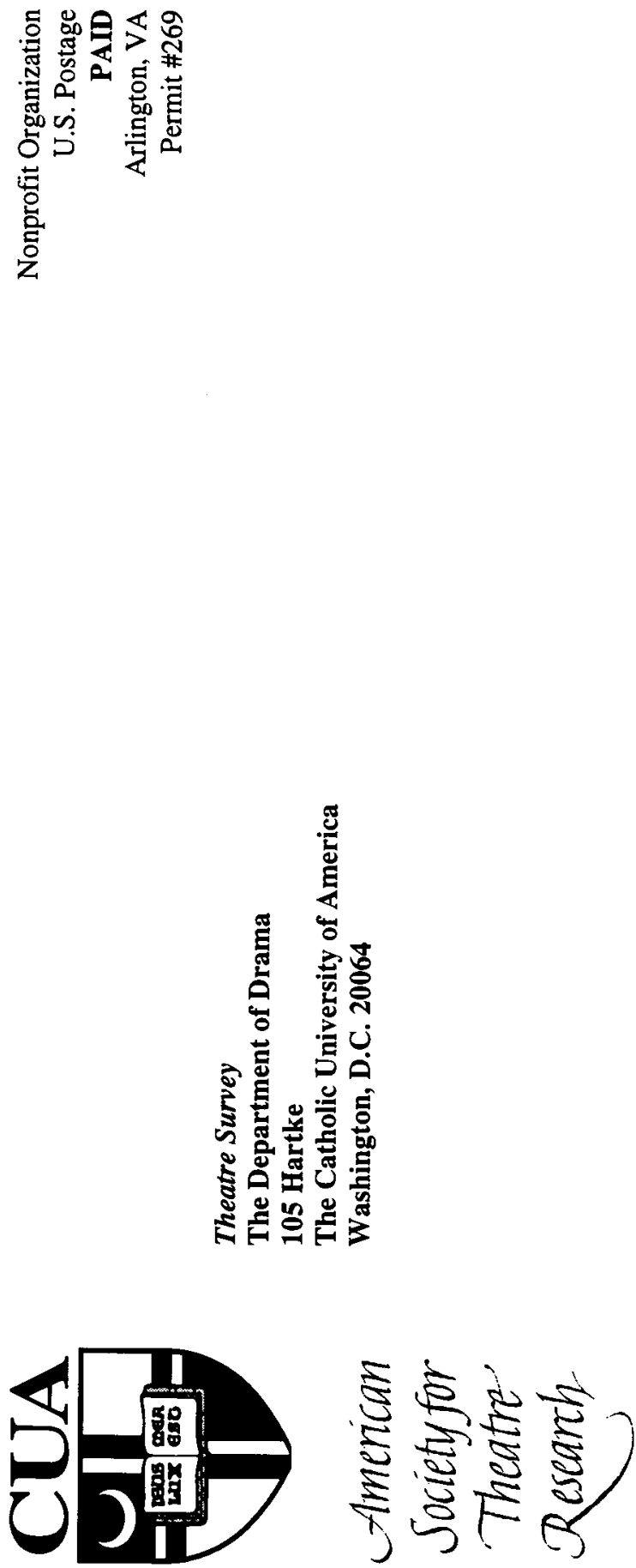